African Crop Science Journal by African Crop Science Society is licensed under a Creative Commons Attribution 3.0 Uganda License. Based on a work at www.ajol.info/ and www.bioline.org.br/cs DOI: https://dx.doi.org/10.4314/acsj.v28i1.8S

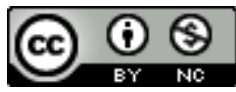

\title{
NUTRITIONAL VALUE OF SAFFLOWER WHOLE SEED AS ANIMAL FEED IN SEMI-ARID SOUTHERN AFRICAN CONDITIONS
}

\author{
D. KEREILWE, V.E. EMONGOR, O. OAGILE and O. PHOLE
}

Department of Crop Science and Production, Botswana University of Agriculture and Natural Resources, Private Bag 0027, Gaborone, Botswana

Corresponding author: vemongor@gmail.com, vemongor@buan.ac.bw

\begin{abstract}
Safflower (Carthamus tinctorius L.) is a multipurpose crop, grown for its high quality edible oil (poly unsaturated and monounsaturated fatty acids), and as a horticultural crop (vegetable and cut flower). It is also grown for flavouring and colouring foods, as herbal tea, livestock feed, pharmaceuticals, dyes, paints and biodiesel.The objective of this study wasto evaluate the influence of safflower genotype on the nutritional quality of whole seed used as livestock feed. Nine safflower genotypes (eight exotic and one local) were grown in winter and summer. The seeds were harvested at physiological maturity and analysed for different nutritional variables. Whole safflower seeds dry matter (DM), crude protein (CP), neutral detergent fibre (NDF), acid detergent fibre (ADF), acid detergent lignin (ADL) and ash varied significantly, depending on genotype and growing season. The seed mineral content $(\mathrm{P}, \mathrm{K}, \mathrm{Mg}$ and $\mathrm{Na})$ also varied across genotypes. Safflower whole seeds have great potential to serve as an excellent livestock feed in semi-arid conditions.
\end{abstract}

Key Words: Carthamus tinctorius, neutral detergent fibre, protein

\section{RÉSUMÉ}

Le carthame (Carthamus tinctorius L.) est une culture polyvalente, cultivée pour son huile comestible de haute qualité (acides gras polyinsaturés et monoinsaturés) et comme culture horticole (légume et fleur coupée). Il est également cultivé pour aromatiser et colorer les aliments, comme les tisanes, les aliments pour le bétail, les produits pharmaceutiques, les colorants, les peintures et le biodiesel. L'objectif de cette étude était d'évaluer l'influence du génotype du carthame sur la qualité nutritionnelle des semences entières utilisées comme aliments pour le bétail. Neuf génotypes de carthame (huit exotiques et un local) ont été cultivés en hiver et en été. Les graines ont été récoltées à maturité physiologique et analysées pour différentes variables nutritionnelles. Les matières sèches (DM) de carthame entier, les protéines brutes (CP), les fibres détergentes neutres (NDF), les fibres détergentes acides (ADF), la lignine détergente acide (ADL) et les cendres varient considérablement selon le génotype et la saison de croissance. La teneur en minéraux des graines $(\mathrm{P}, \mathrm{K}, \mathrm{Mg}$ et $\mathrm{Na}$ ) variait également d'un génotype à l'autre. Les graines de carthame entières ont un grand potentiel pour servir d'excellent aliment pour le bétail dans des conditions semi-arides.

Mots Clés: Carthamus tinctorius, fibre détergente neutre, protéine 


\section{INTRODUCTION}

Safflower (Carthamus tinctorius L.) is a multipurpose oil seed crop that is drought, heat, cold and salinity tolerant.It is one of the neglected and minor crops around the globe (Weiss, 2000; Emongor, 2010). It is good for human consumption, as well as for animal feeding mostly in the form of hay or silage (Bar-Tal et al., 2008). Safflower forage has been reported to be palatable, with feed values and yields similar to or better than oats and alfalfa (Smith, 1996; Wichman, 1996; Berglund et al., 2007). Grazed safflower has been shown to support satisfactory growth rates in Australian steers (French et al., 1988) and improve fertility in Canadian ewes (Stanford et al., 2001).

Safflower oil cake is reportedly a valuable animal feed (Weiss, 2000). Hulled safflower cake has been reported to contain protein and fibre of 20-25 and up to 60\% (Voicu et al., 2009; Chidoh, 2012; Jacob, 2015). Safflower cakes produced from dehulled safflower seeds can contain protein and fibre contents of 35$50 \%$ and $10-15 \%$ fibre (Voicu et al., 2009; Jacob, 2015). The hull is the main source of fibre in the seed, so the level of crude fiber in safflower cake varies depending on the level of hulls remaining (Voicu et al., 2009; Jacob, 2015).

The safflower cake from dehulled seeds can be used in compound feeds for pigs and poultry as a source for supplemental amino acids lysine, methionine and cysteine (Voicu et al., 2009). The safflower cake with high fibre content has been recommended for ruminant feed (Voicu et al., 2009; Dschaak et al., 2010; Jacob, 2015).

In Botswana, annual precipitation and evapotranspiration ranges between 200-650 $\mathrm{mm}$ and $1800-3000 \mathrm{~mm}$, respectively, depending on season (Emongor et al., 2008). Rainfall is erratic, unreliable and poorly distributed, yet it is accompanied by high temperatures, and water is by far the most limiting factor to agricultural production (Emongor, 2009). Drought is a common phenomenon which negatively affects the already fragile food and agricultural situation in the country. During drought and the winter dry months livestock feed is scarce and imported feeds become expensive for livestock farmers. Therefore, growing a drought, saline and winter tolerant crop such as safflower will improve food security, reduce reliance on feed imports and improve income levels of farmers in Botswana.The objective of this study was to evaluate the influence of safflower genotype on the nutritional quality of whole seed when used as livestock feed.

\section{MATERIALS AND METHODS}

Experimental site. A field experiment was conducted in winter and summer growing seasons, at the Botswana University of Agriculture and Natural Resources Content Farm, situated at Notwane, Sebele, (243' S: $25^{\circ} 58^{\prime}$ E) at an altitude of $998 \mathrm{~m}$ above sea level. The trials were done between May October 2015 (winter) and January-April 2016 (summer).The experimental site had mean maximum and minimum temperature of 33.134.7 and $19.2-19.5^{\circ} \mathrm{C}$, respectively. The rainfall amount varied between $250-600 \mathrm{~mm}$ per annum. The soils are deep and of sandy loam texture.

Experimental design and management. The genotypes evaluated included Kiama Composite (local cultivar used as control), PI-5376321038-USA, PI-3044-BJ-2621-Iran, PI537598-Sina-USA, PI-407616-BJ-2131Turkey, PI-537634-1040-USA, PI-537668BJ-1085-USA, PI-314650-Milutin-114Kazakhistan, and PI-306830-BJ-1632India.The experimental design was a randomised complete block design, with three replications. Blocking was done in order to spread the effects of the $1 \%$ slope in the experimental site. 
Safflower was planted in single rows in experimental units measuring $5 \mathrm{~m} \times 5 \mathrm{~m}$. Seeds were sown at a depth of $6 \mathrm{~mm}$. Plant spacing was $0.40 \mathrm{~m}$ (inter-row) by $0.25 \mathrm{~m}$ (intra-row).

Field preparation was done using a disc plough, then harrowed to to achievea fine tilth for seed sowing. Weeding was done using a hoe, by cultivating between rows throughout the crop growth cycle. Irrigation was done once a week for 2 hours (11 mm-pump discharge rate to sprinklers measured by propeller flow metre). Fertiliser application was done at $80 \mathrm{~kg} \mathrm{~N} \mathrm{ha}^{-1}$ (calcium ammonium nitrate $-28 \% \mathrm{~N}$ ) and $50 \mathrm{~kg} \mathrm{P} \mathrm{ha}^{-1}$ (single super phosphate-10.5\% P).

After plants reached physiological maturity, plants were harvested in an area of $4 \mathrm{~m}^{2}$ in the centre of the experimental plots. Seeds were threshed and weighed to determine seed yield per hectare. The seeds harvested served as experimental samples. All the plants within the $4 \mathrm{~m}^{2}$ in the centre of the experimental plots were used in seed harvesting.

Dry matter (DM) was determined by oven drying seeds for 72 hours at $66^{\circ} \mathrm{C}$, to constant mass (AOAC, 2000). The dried samples were ground in a mill to pass a $1 \mathrm{~mm}$ sieve for further laboratory analyses. Crude protein was determined using the Kjeldahl digestion method (AOAC, 2000). Assays for neutral detergent fibre (NDF) and acid detergent fibre (ADF) were done according to AOAC (2000). Foracid detergent lignin (ADL) analysis was performed using the adaptation of Van Soest detergent Scheme (ANKOM Daisy II Incubator), which utilises the ADF method (Van Soest et al., 1991).

The amount of ash in the samples was ascertained by completely burning to ash, samples previously used in ADL procedure (ANKOM method) in a muffle furnace at 550 to $600{ }^{\circ} \mathrm{C}$ for 2 hours (AOAC, 2000). Crude protein was analysed using Elemental Analysis for dummies System (EAS), 2010.

For mineral analysis, $0.5 \mathrm{~g}$ of previously grounded safflower whole seeds were first digested in $10 \mathrm{ml}$ of concentrated sulphuric acid $(98 \%)$, and $2 \mathrm{ml}$ of $15-45 \%$ hydrogen peroxide in a digestion block at $420{ }^{\circ} \mathrm{C}$ for 8 hours. After digestion, samples were allowed to cool for 2 hours and then transferred into $200 \mathrm{ml}$ volumetric flasks, before filling with distilled water to the mark. Analyses for P, K, $\mathrm{Ca}, \mathrm{Mg}, \mathrm{Na}, \mathrm{Fe}, \mathrm{Zn}, \mathrm{Mn}$ and $\mathrm{Cu}$ were determined using Inductively Coupled Plasma mass spectrometry (ICP-MS) (AOAC, 2000).

Data analysis. Data collected were subjected to analysis of variance (ANOVA) using the General Linearised Models (Proc GLM) procedure of the Statistical Analysis System (SAS) Programme. Significant treatment means were separated using the Least Significant Difference (LSD) at 5\% level of significance.

\section{RESULTS}

The effects of safflower genotype on whole seed DM, ash, CP and fibre are presented in Tables 1 and 2. Safflower genotypes grown either in winter or summer did not significantly $(\mathrm{P}>0.05)$ differ in DM content (Table 1). The whole seed DM content ranged between 94.596.1 and 91.9-94.5\% in winter and summer grown plants, respectively. The average DM of safflower grown in winter was $95.4 \%$, which was significantly $(\mathrm{P}<0.05)$ higher than DM content of $93.4 \%$ for summer grown plants (Table 1).

The whole seed ash content of safflower genotypes grown in winter differed significantly $(\mathrm{P}<0.05)$ (Table 1$)$. Genotype PI-537634-1040-USA had ash content of $1.41 \%$, which was significantly $(\mathrm{P}<0.05)$ higher than the ash contents of the genotypes Kiama Composite, PI-537668-BJ-1085-USA, PI-314650-Milutin-114-Kazakhistan, and PI306830-BJ-1632-India, when grown in winter. However, ash content of genotype PI-5376341040-USA grown in winter did not differ significantly $(\mathrm{P}>0.05)$ from ash contents of genotypes PI-537632-1038-USA, PI-3044-BJ2621-Iran, PI-537598-Sina-USA and PI 407616-BJ-2131-Turkey (Table 1). 
TABLE 1. Effect of safflower genotype on safflower whole seed dry matter, ash and crude protein grown in winter and summer in Botswana

\begin{tabular}{|c|c|c|c|c|c|c|}
\hline \multirow[t]{2}{*}{ Genotype } & \multicolumn{2}{|c|}{$\mathrm{DM}(\%)$} & \multicolumn{2}{|c|}{ Ash $(\%)$} & \multicolumn{2}{|c|}{$\mathrm{CP}(\%)$} \\
\hline & Winter & Summer & Winter & Summer & Winter & Summer \\
\hline Kiama composite & 95.5 & 92.2 & 1.0 & 1.24 & 17.1 & 16.8 \\
\hline PI-537632-1038-USA & 96.1 & 94.1 & 1.23 & 1.16 & 18.1 & 17.4 \\
\hline PI-30441-BJ-2621-Iran & 95.2 & 93.1 & 1.28 & 1.14 & 18.2 & 19.1 \\
\hline PI-537598-SINA-USA & 94.5 & 94.5 & 1.1 & 1.19 & 16.7 & 16.9 \\
\hline PI-407616-BJ-2131-Turkey & 95.7 & 91.9 & 1.13 & 1.14 & 18.5 & 17.6 \\
\hline PI-537634-1040-USA & 94.7 & 94.5 & 1.41 & 1.24 & 17.6 & 16.9 \\
\hline PI-537668-BJ-1085-USA & 95.8 & 92.8 & 0.95 & 1.22 & 17.6 & 17.0 \\
\hline PI-314650-Milutin-114 & 95.5 & 93.8 & 0.96 & 1.16 & 16.3 & 17.0 \\
\hline PI-306830-BJ-1632-India & 95.5 & 93.7 & 1.05 & 1.2 & 18.1 & 18.2 \\
\hline Significance & NS & NS & $*$ & NS & NS & $*$ \\
\hline $\operatorname{LSD}(0.05)$ & 1.64 & 3.66 & 0.35 & 0.19 & 4.07 & 1.24 \\
\hline
\end{tabular}

* = NS, Significant at $\mathrm{P}=0.05$ and non-significant, respectively. $\mathrm{DM}=$ Dry matter, $\mathrm{CP}=\mathrm{Crude}$ protein

TABLE 2. Effect of safflower genotype whole seed fiber content grown in winter and summer in Botswana

\begin{tabular}{|c|c|c|c|c|c|c|}
\hline \multirow[t]{2}{*}{ Genotype } & \multicolumn{2}{|c|}{$\operatorname{NDF}(\%)$} & \multicolumn{2}{|c|}{$\operatorname{ADF}(\%)$} & \multicolumn{2}{|c|}{$\operatorname{ADL}(\%)$} \\
\hline & Winter & Summer & Winter & Summer & Winter & Summer \\
\hline Kiama composite & 49.0 & 46.0 & 48.0 & 43.6 & 19.0 & 14.9 \\
\hline PI-537632-1038-USA & 48.0 & 43.9 & 46.0 & 41.3 & 14.0 & 14.0 \\
\hline PI-30441-BJ- 2621-Iran & 46.0 & 42.6 & 47.3 & 43.9 & 19.3 & 16.0 \\
\hline PI-537598-SINA-USA & 47.7 & 45.3 & 44.5 & 43.3 & 19.6 & 15.3 \\
\hline PI-407616-BJ-2131-Turkey & 47.3 & 45.0 & 44.3 & 39.7 & 17.5 & 13.5 \\
\hline PI-537634-1040-USA & 43.3 & 44.7 & 47.3 & 43.3 & 18.7 & 15.3 \\
\hline PI-537668-BJ-1085-USA & 50.3 & 46.7 & 46.7 & 44.6 & 20.7 & 15.3 \\
\hline PI-314650-Milutin-114 & 49.3 & 45.5 & 42.8 & 41.6 & 17.4 & 14.2 \\
\hline PI-306830-BJ-1632-India & 48.7 & 46.7 & 43.2 & 42.2 & 15.3 & 15.4 \\
\hline Significance & $* *$ & $* * * *$ & $*$ & $*$ & $* * *$ & $*$ \\
\hline $\operatorname{LSD}(0.05)$ & 3.24 & 1.54 & 4.04 & 3.13 & 2.82 & 2.44 \\
\hline
\end{tabular}

$*, * *, * * *, * * * *$ Significant at $\mathrm{P}=0.05,0.01,0.001$ and 0.0001 , respectively. NDF $=$ Neutral detergent fibre, $\mathrm{ADF}=$ Acid detergent fibre, and $\mathrm{ADL}=$ Acid detergent lignin 
During summer, safflower genotypes did not significantly $(\mathrm{P}>0.05)$ differ in their whole seed ash content (Table 1). The whole seed ash content ranged between $0.95-1.41 \%$ and $1.14-1.24 \%$ in winter and summer grown, respectively. The average whole seed ash content was 1.12 and $1.19 \%$ in winter and summer grown safflower, respectively (Table 1).

Safflower genotypes did not significantly $(\mathrm{P}>0.05)$ differ in whole seed $\mathrm{CP}$ content (Table 1). However, in summer safflower genotypes had significant $(\mathrm{P}<0.05)$ different contents of whole seed CP (Table 1). Genotype PI-3044-BJ-2621-Iran had whole seed CP content of $19.1 \%$, which was significantly ( $\mathrm{P}$ $<0.05$ ) higher than the $\mathrm{CP}$ values of all other the genotypes, except for genotype PI-306830BJ-1632-India (Table 1). Whole seed CP content ranged between $16.3-18.5 \%$ and 16.8 $19.1 \%$ in winter and summer grown plants, respectively. On average, whole seed $\mathrm{CP}$ content was only slightly higher in safflower grown in winter $(17.6 \%)$ than summer $(17.4 \%)$.

There were significant $(\mathrm{P}<0.05)$ differences among safflower genotypes either grown in winter or summer, with respect to crude fibre (Table 2). In winter, genotype PI537668-BJ-1085-USA had NDF of 50.3\%; which was significantly $(\mathrm{P}<0.05)$ higher than NDF of genotypes PI-3044-BJ-2621-Iran (46.0\%) and PI-537634-1040-USA (43.3\%), but had statistically similar NDF with other genotypes (Table 2). Whole seed NDF ranged between 43.3-50.3 and 42.6-46.7\% in winter and summer grown safflower, respectively (Table 2). The winter $(47.7 \%)$ grown safflower had significantly $(\mathrm{P}<0.05)$ higher whole seed NDF than its summer (45.2\%) grown counterpart (Table 2). Genotype and growing season significantly $(\mathrm{P}<0.05)$ influenced safflower whole seed ADF (Table 2). Variation in whole seed ADF ranged between $42.8-48.0$ and $39.7-44.6 \%$ in winter and summer, respectively (Table 2). Furthermore, whole seed ADF was significantly $(\mathrm{P}<0.05)$ higher in winter than summer growing season (Table 2). In winter, Kiama composite $(48.0 \%)$ had the highest whole seed ADF, but was not statistically ( $\mathrm{P}>$ 0.05 ) different from all other varieties apart from PI-306830-BJ-1632-India and PI314650-Milutin-114-Kazakistan with 43.3 and $42.8 \%$ whole seed ADF, respectively (Table 2). Similarly, in summer, all other safflower genotypes were not statistically $(\mathrm{P}>0.05)$ different from each otherin terms of ADF. The exception was that of PI-537668-BJ-1085USA, PI-30441-BJ-2621-Iran and PI-407616BJ-2131-Turkey, which were significantly ( $P$ $<0.05$ ) different from each other (Table 2).

Whole seed ADL significantly $(\mathrm{P}<0.05)$ differed depending on the genotype and growing season (Table 2). Seed ADL ranged between $14.0-20.7 \%$ and $13.5-16.0 \%$ in winter and summer grown plants, respectively (Table 2). In winter, genotype PI-537668-BJ-1085USA $(20.7 \%)$ had significantly $(P<0.05)$ higher whole seed ADL than genotypes PI407616-BJ-2131-Turkey, PI 314650-Milutin114-Kazakistan and PI-306830-BJ-1632-India (Table 2). It was, however, not statistically (P $>0.05$ ) different from genotypes PI-5376341040-USA, PI-537598-Sina-USA, Kiama composite and PI-30441-BJ-2621-Iran (Table 2). In winter grown safflower, genotype PI537598-Sina-USA also had significantly $(\mathrm{P}<$ 0.05 ) higher whole seed ADL than the genotypes PI-306830-BJ-1632-India and PI537632-1038-USA (Table 2). While in summer grown safflower, there were no significant $(P$ $>0.05)$ differences between safflower genotypes with respect to whole seed ADL contents. The only exception was that of genotype PI-30441-BJ-2621-Iran, which had significantly $(\mathrm{P}<0.05)$ higher whole seed ADL content than genotype PI-407616-BJ-2131Turkey (Table 2).

The phosphorus content of safflower whole seed significantly $(\mathrm{P}<0.01)$ varied acrossgenotypes (Table 3). Phosphorus content in whole seed varied between 5.47$7.87 \mathrm{mg} \mathrm{g}^{-1}$ depending on safflower genotypes 
TABLE 3. Macro-mineral composition of safflower whole seed grown in winter in Botswana

\begin{tabular}{lccccc}
\hline Genotype & \multicolumn{5}{c}{ Mineral content $\left(\mathrm{mg} \mathrm{g}^{-1}\right)$} \\
\cline { 2 - 5 } & $\mathrm{P}$ & $\mathrm{K}$ & $\mathrm{Ca}$ & $\mathrm{Mg}$ & $\mathrm{Na}$ \\
\hline Kiama composite & 6.20 & 10.25 & 9.50 & 4.69 & 3.42 \\
PI-537632-1038-USA & 6.08 & 10.92 & 10.53 & 4.75 & 3.41 \\
PI-30441-BJ-2621-Iran & 5.65 & 8.44 & 9.92 & 4.54 & 3.24 \\
PI-537598-SINA-USA & 6.60 & 11.13 & 9.95 & 5.38 & 3.57 \\
PI-407616-BJ-2131-Turkey & 6.61 & 9.34 & 9.45 & 4.72 & 3.31 \\
PI-537634-1040-USA & 6.77 & 12.04 & 11.06 & 4.80 & 3.28 \\
PI-537668-BJ-1085-USA & 5.47 & 9.91 & 11.16 & 4.37 & 3.45 \\
PI-314650-MILUTIN-114 & 7.08 & 10.27 & 10.48 & 5.28 & 3.40 \\
PI-306830-BJ-1632-India & 7.87 & 12.26 & 11.33 & 5.55 & 3.54 \\
& & & & & $*$ \\
Significance & $* *$ & $* * * *$ & $*$ & $*$ & 0.24 \\
LSD(0.05) & 1.32 & 1.36 & 1.43 & 0.81 & \\
\hline
\end{tabular}

$*, * *, * * * *$ Significant at $\mathrm{P}=0.05,0.01$ and 0.0001 , respectively. Means separated using the Least Significant Difference (LSD) at $\mathrm{P}=0.05$

(Table 3). Genotype PI-306830-BJ-1632-India had the highest $\mathrm{P}$ content $\left(7.87 \mathrm{mg} \mathrm{g}^{-1}\right)$ in safflower whole seed and was significantly $(\mathrm{P}$ $<0.05$ ) higher than whole seed $\mathrm{P}$ contents of genotypes Kiama composite, PI-537632-1038USA, PI-30441-BJ-2621-Iran and PI-537668BJ-1085-USA (Table 3). However, whole seed $\mathrm{P}$ content of genotype PI 306830-BJ-1632India did not significantly $(\mathrm{P}>0.05)$ differ with that of genotypes PI-314650-MilutinKazakistan, PI-537634-1040-USA, PI 407616BJ-2131-Turkey and PI-537598-Sina-USA (Table 3). Also, whole seed P content of genotypes Kiama Composite, PI-30441-BJ2621-Iran, PI-537668-BJ-1085-USA, PI407616-BJ-2131-Turkey, PI-537632-1038USA, PI-537598-Sina-USA and PI-5376341040-USA did not differ significantly $(\mathrm{P}>$ 0.05) (Table 3).

There were also significant $(\mathrm{P}<0.05)$ differences in the whole seed potassium $(\mathrm{K})$ content of the genotypes (Table 3 ). The $\mathrm{K}$ content of the genotypes varied between 8.44$12.26 \mathrm{mg} \mathrm{g}^{-1}$ (Table 3). Genotype PI-306830$\mathrm{BJ}-1632-$ India had the highest whole seed $\mathrm{K}$ content of $12.26 \mathrm{mg} \mathrm{g}^{-1}$ and it was significantly $(\mathrm{P}<0.0001)$ higher than that of genotypes PI-314650-Milutin-114-Kazakistan, Kiama Composite, PI-537668-BJ-1085-USA, PI 407616-BJ-2131-Turkey and PI-30441-BJ2621-Iran (Table 3). However, whole K seed content of genotype PI-306830-BJ-1632-India did not significantly $(\mathrm{P}>0.05)$ differ with that of genotypes PI-537634-1040-USA, PI537598-Sina-USA and PI-537632-1038-USA (Table 3). Genotype PI-30441-BJ-2621-Iran had the lowest whole seed $\mathrm{K}$ content of 8.44 $\mathrm{mg} \mathrm{g}^{-1}$ but was not significantly $(\mathrm{P}>0.05)$ different from whole seed $\mathrm{K}$ content of the genotype PI-407616-BJ-2131-Turkey (Table 3).

Safflower genotypes significantly $(\mathrm{P}<0.05)$ influenced whole seed calcium $(\mathrm{Ca})$ content (Table 3). The whole seed Ca content ranged between 9.45-11.33 $\mathrm{mg} \mathrm{g}^{-1}$ (Table 3). Genotype PI- 306830-BJ-1632-India had whole seed Ca content of $11.33 \mathrm{mg} \mathrm{g}^{-1}$ which was significantly $(\mathrm{P}<0.05)$ higher than that of the genotypes Kiama Composite and PI 407616-BJ-2131Turkey, but was not significantly $(\mathrm{P}>0.05)$ 
different from the whole seed Ca content of other genotypes (Table 3). The genotypes PI537668-BJ-1085-USA and PI-537634-1040USA had the highest value of Ca content, but did not differ significantly $(\mathrm{P}>0.05)$ with the Ca content of the genotypes PI-537632-1038USA, PI-314650-Milutin-114-Kazakistan, PI537598-Sina-USA and PI-30441-BJ-2621-Iran (Table 3). However, the Ca content of the genotypes PI-537668-BJ-1085-USA and PI537634-1040-USA was significantly $(\mathrm{P}<0.05)$ higher than that of Kiama Composite and PI407616-BJ-2131-Turkey (Table 3). Genotype Kiama Composite had the lowest whole seed Ca content of $9.45 \mathrm{mg} \mathrm{g}^{-1}$, but not significantly ( $\mathrm{P}>0.05)$ different from the whole seed $\mathrm{Ca}$ content of genotypes PI-537632-1038-USA, PI-314650-Milutin-114-Kazakistan, PI537598-Sina-USA and PI-30441-BJ-2621-Iran (Table 3).

Safflower genotype significantly $(\mathrm{P}<0.05)$ influenced whole seed magnesium $(\mathrm{Mg})$ content (Table 3). Whole seed Mg content ranged between $4.37-5.55 \mathrm{mg} \mathrm{g}^{-1}$ depending on genotype (Table 3). Genotype PI-306830BJ-1632-India had whole seed Mg content of $55 \mathrm{mg} \mathrm{g}^{-1}$, which was significantly $(\mathrm{P}<0.05)$ higher than whole seed $\mathrm{Mg}$ content of genotypes PI-407616-BJ-2131-Turkey, Kiama Composite, PI-30441-BJ-2621-Iran and PI537668-BJ-1085-USA, which had whole seed $\mathrm{Mg}$ contents of $4.72,4.69,4.54,4.37 \mathrm{mg}$ $\mathrm{g}^{-1}$, respectively (Table 3). However, whole seed Mg content of genotype PI-306830-BJ1632-India was not significantly $(\mathrm{P}>0.05)$ different from that of the genotypes PI537598-Sina-USA (5.38 $\mathrm{mg} \mathrm{g}^{-1}$ ), PI-314650Milutin-114-Kazakistan (5.28 $\left.\mathrm{mg} \mathrm{g}^{-1}\right)$, PI537634-1040-USA (4.80 $\left.\mathrm{mg} \mathrm{g}^{-1}\right)$ and PI537632-1038-USA (4.75 $\mathrm{mg} \mathrm{g}^{-1}$ ) (Table 3).

Genotype PI 537668-BJ-1085-USA had the lowest whole seed $\mathrm{Mg}$ content of $4.37 \mathrm{mg} \mathrm{g}^{-1}$, but was not significantly $(\mathrm{P}>0.05)$ different from whole seed $\mathrm{Mg}$ contents of the genotypes Kiama Composite, PI-537634-1040-USA, PI537632-1038-USA, PI-407616-BJ-2131Turkey and PI-30441-BJ-2621-Iran (Table 3).
Sodium content of safflower whole seed significantly $(\mathrm{P}<0.05)$ differed depending on genotype (Table 3 ). Whole seed $\mathrm{Na}$ content ranged between 3.24-3.57 $\mathrm{mg} \mathrm{g}^{-1}$, depending genotype (Table 3). Genotype PI-537598-SinaUSA had significantly $(\mathrm{P}<0.05)$ higher whole seed Na content than genotypes PI-407616BJ-2131-Turkey, PI-537634-1040-USA and PI-30441-BJ-2621-Iran (Table 3). However, genotype PI-537598-Sina-USA which had the highest whole seed $\mathrm{Na}$ content of $3.57 \mathrm{mg} \mathrm{g}^{-1}$ was not significantly $(\mathrm{P}>0.05)$ different from whole seed $\mathrm{Na}$ content of genotypes Kiama Composite, PI-537632-1038-USA, PI537668-BJ-1085-USA, PI-306830-BJ-1632India and PI-314650-Milutin-114-Kazakisatan (Table 3). Genotype PI-537634-1040-USA had the lowest whole seed $\mathrm{Na}$ content of $3.24 \mathrm{mg}$ $\mathrm{g}^{-1}$, but was not significantly $(\mathrm{P}>0.05)$ from the whole seed Na content of genotypes Kiama Composite, PI-537632-1038-USA, PI-30441BJ-2621-Iran, PI-537668-BJ-1085-USA, PI407616-BJ-2131-Turkey and PI-314650Milutin-114-Kazakisatan (Table 3).

Micro-nutrient mineral composition of safflower whole seeds grown in winter are presented in Table 4. Zinc content of safflower whole seed significantly $(\mathrm{P}<0.05)$ varied across genotypes (Table 4 ). Whole seed $\mathrm{Zn}$ content of safflower seeds ranged between 90 and $120 \mu \mathrm{g} \mathrm{g}^{-1}$ (Table 4). Genotypes PI306830-BJ-1632-India and PI-537598-SinaUSA had similar whole seed Zn content of 120 $\mu \mathrm{g} \mathrm{g}^{-1}$, which was significantly $(\mathrm{P}<0.05)$ higher than whole seed $\mathrm{Zn}$ content of the genotype PI-30441-BJ-2621-Iran, but was not significantly $(\mathrm{P}>0.05)$ different from the whole seed $\mathrm{Zn}$ content of the other genotypes (Table 4).

Safflower genotypes significantly $(\mathrm{P}<0.01)$ influenced the iron $(\mathrm{Fe})$ content of safflower whole seed (Table 4). Whole seed Fe content ranged between 50-80 $\mathrm{g} \mathrm{g} \mathrm{g}^{-1}$ (Table 4). Genotype PI-537598-Sina-USA had significantly $(\mathrm{P}<0.01)$ higher whole seed $\mathrm{Fe}$ content than PI-537668-BJ-1085-USA, but was not significantly $(\mathrm{P}>0.05)$ different from 
TABLE 4. Micro-mineral composition of safflower whole seed grown in winter in Botswana

\begin{tabular}{lcccc}
\hline Genotype & \multicolumn{3}{c}{ Mineral content $\left(\mu \mathrm{g} \mathrm{g}^{-1}\right)$} \\
\cline { 2 - 5 } & $\mathrm{Zn}$ & $\mathrm{Fe}$ & $\mathrm{Mn}$ & $\mathrm{Cu}$ \\
\hline Kiama composite & 110 & 70 & 40 & 170 \\
PI-537632-1038-USA & 110 & 60 & 40 & 160 \\
PI-30441-BJ-2621-Iran & 90 & 60 & 30 & 150 \\
PI-537598-SINA-USA & 120 & 80 & 40 & 160 \\
PI-407616-BJ-2131-Turkey & 110 & 70 & 50 & 140 \\
PI-537634-1040-USA & 100 & 70 & 40 & 140 \\
PI-537668-BJ-1085-USA & 100 & 50 & 30 & 140 \\
PI-314650-MILUTIN-114 & 100 & 70 & 30 & 150 \\
PI-306830-BJ-1632-India & 120 & 70 & 50 & 140 \\
& & & $* *$ & $\mathrm{NS}$ \\
Significance & $*$ & $* *$ & 10 & 40 \\
LSD $(0.05)$ & 20 & 20 & & \\
\hline
\end{tabular}

*, **, NS, Significant at $\mathrm{P}=0.05,0.01$ and non-significant, respectively. Means separated using the Least Significant Difference (LSD) at $\mathrm{P}=0.05$.

whole seed Fe contents of other genotypes (Table 4).

Safflower genotypes significantly $(\mathrm{P}<0.05)$ differed in their whole seed manganese (Mn) content (Table 4). Whole seed Mn content of safflower seeds ranged between 30-50 $\mu \mathrm{g} \mathrm{g}^{-1}$ depending on genotype (Table 4). Safflower genotypes PI-306830-BJ-1632-India and PI407616-BJ-2131-Turkey had whole seed Mn content of $50 \mu \mathrm{g} \mathrm{g}^{-1}$, which was significantly $(\mathrm{P}<0.01)$ higher than the whole seed $\mathrm{Mn}$ content of genotypes PI-314650-Milutin-114Kazakistan, PI-537668-BJ-1085-USA and PI30441-BJ-2621-Iran (Table 4). However, whole seed Mn content of the genotypes PI306830-BJ-1632-India and PI-407616-BJ2131-Turkey did not significantly $(\mathrm{P}>0.05)$ differ from the whole seed Mn content of genotypes PI-537598-Sina-USA, PI-5376321038-USA, Kiama Composite and PI-5376341040-USA (Table 4). On the contrary, the whole seed copper $(\mathrm{Cu})$ content of safflower did not significant $(\mathrm{P}>0.05)$ differ with genotype (Table 4). Whole seed $\mathrm{Cu}$ content of safflower ranged between 140-170 $\mu \mathrm{g} \mathrm{\textrm {g } ^ { - 1 }}$ depending on genotype (Table 4).

\section{DISCUSSION}

Results of this study have shown that, despite the significant genetic effects of safflower on whole seed nutritional composition, ash, macro- and micro-nutrients, levels of DM, CP, crude fibre (NDF, ADF and ADL), macro- and micro-mineral nutrients ( $\mathrm{P}, \mathrm{K}, \mathrm{Ca}, \mathrm{Mg}, \mathrm{Fe}, \mathrm{Na}$, $\mathrm{Zn}, \mathrm{Fe}, \mathrm{Mn}$ and $\mathrm{Cu}$ ) were within the nutritional contents used to qualify an animal feed for quality purposes. According to Van Saun (2016) and Ball et al. (2017), the potential animal feed should contain greater than $85 \%$ $\mathrm{DM}$, greater than $9 \% \mathrm{CP}, 50-60 \% \mathrm{NDF}$, less than $35 \% \mathrm{ADF}$ and $1-4 \%$ ash content on DM basis. Safflower whole seed, depending on genotype and growing season, contained DM, crude fibreand ash contents which were within the recommended range for animal feed(Tables 1 and 2).

The level of whole seed DM suggests that whole seeds of safflower genotypes used in this study can serve as excellent quality livestock feed for beef and dairy animals. Walker (2006) and Malakian et al. (2011) also reported whole safflower seeds to contain 94.4 
and $93 \%$ DM, respectively. With the exception of the safflower genotype PI-537598-SinaUSA, all genotypes in the present study had significantly $(\mathrm{P}<0.05)$ higher whole seed DM in winter than summer growing seasons. Winter grown safflower plants accumulated more seed DM matter than their summer counterparts because of the longer maturation period of about 138 days after emergence in winter compared to summer with 90 days after emergence in summer. Research by Nepal Government (2012) reported that whole safflower seed contained $13.5 \% \mathrm{CP}$ which was acceptable based on the protein requirements of livestock. In Australia, safflower whole seed was fed to beef and dairy cattle and sheep as feed supplement, or mixed in feed rations (OGTR, 2015). Bottger et al. (2002) reported that lactating beef cows fed with high-linoleate safflower whole seeds were capable of maintaining good body condition. The present study has demonstrated that, all safflower genotypes investigated can be used as sources of protein for livestock feed, especially ruminants.

It is clear from the present study that whole safflower seed NDF, which ranged between 46.0 and $50.3 \%$ was of high nutritional quality for feed for livestock. All genotypes used in the study produced seeds that could be used to formulate high quality animal feed. Godfrey (2006) reported that safflower whole seeds contain between 34.3 and $50.7 \%$ NDF, depending on genotype; which was somewhat inferior to the observations in the present study. Malakian et al. (2011) and Oguz et al. (2007) also reported that safflower whole seeds contained about 40-45\% NDF.

Results of the present study showed that whole seed ADF ranged between 39.7 - 48.0\% depending on safflower genotype and growing season (Table 2). The results implythat safflower whole seeds were less digestible, contradicting findings of several workers (Godfrey, 2006; Malakian et al., 2011; Oguz et al,. 2014), who reported that safflower whole seeds contained less than 35\% ADF.
The contradiction between our results and those of the otherscould be attributed to genotype and environmental differences.

Walker (2006) and Alobeid et al. (2010) reported that safflower whole seeds contained 40.0 and $50 \% \mathrm{ADF}$, respectively, and they concluded that fibres alone should not be used to qualify an animal feed, but other variables such as CP, mineral content and DM should also be considered. In light of this result and the contradictory observations made above, to achieve the desirable ADF, the genotypes used in the present study could be dehulled before being used for livestock feed. The quality of the whole safflower seed used for livestock feed is reported to be variable depending on the amount of hulls (Dajue and Mündel, 1996; Dschaak et al., 2010; Jacob, 2015). Dehulled safflower seeds contains protein and fiber of about $35-50 \%$ and $10-15 \%$ fiber, respectively (Gohl, 1982; Voicu et al., 2009; Jacob, 2015). Alternatively, safflower genotypes with lower hull percentage could be introduced to Botswana for this purpose.

In the present study, whole seed ADL ranged between 13.5 - 20.7\% depending on safflower genotype and growing season (Table 2). Our results indicated that safflower whole seeds had low ADL thus, would lead to high livestock feed intake and digestibility. The present results are in agreement with those of Dixon et al. (2003), who reported that safflower whole seed contained an ADL value of $15.5 \%$. Acid detergent lignin measures the amount of lignin contained in an animal feed. Lignin is indigestible and hence has a negative impact on cellulose digestibility. As lignin content in a feed increases, digestibility of cellulose decreases, thereby lowering the amount of energy potentially available to the animal (Ball et al., 2017). Moreover, at high ADL, NDF and ADF contents in animal feed, feed intake and digestibility decreases, and animal productivity may decrease (Van Saun, 2016; Ball et al., 2017). The present results demonstrated that whole safflower had 
excellent values of NDF and ADL, but ADF was high and could be lowered by dehulling.

Whole seed ash content was between 0.95 and $1.41 \%$ on DM basis, depending on safflower genotype and growing season, but was within the normal range for animal feed (Schroeder, 2012; Van Saun, 2016). Ash is the total mineral content of animal feed, and it does not separate individual minerals (macro-and micro-minerals) of interest from silica and other less important minerals (Van Saun, 2016; Ball et al., 2017). It is important to understand what constitutes the normal ash content of a feed because if ash content is abnormally high, there is a high possibility that the feed is contaminated with soil which is undesirable (Hoffman and Tayson, 2005). Safflower whole seed has been reported to contain 2.10$5.54 \%$ ash (Nagaraj, 1993; Rahamatalla et al., 1998; Malakian et al., 2011). The results of the current study confirmed that safflower whole seed are an excellent source of minerals for livestock feed.

Genetic variation in mineral composition of safflower whole seeds was also observed in the current study (Table 3). The P, K, Ca, Mg, $\mathrm{Na}, \mathrm{Zn}, \mathrm{Fe}, \mathrm{Mn}$ and $\mathrm{Cu}$ contents in the present study showed that safflower whole seeds can provide both macro- and micro-nutrients to livestock. The $\mathrm{P}$ requirement in livestock is reported to be between $0.25-0.30 \%$ (NRC, 2001). The safflower whole seed $\mathrm{Ca}: \mathrm{P}$ ratio was $1.6: 1$, while the desirable $\mathrm{Ca}: \mathrm{P}$ ratio in livestock feed should be between 2:1 and 1:1 (IPNI, 1999). It was reported that whole safflower seeds contain $0.32-0.67 \%$ P (USDH, 2010; Nepal Government, 2012; Heuze et al., 2012).

NRC (2001) reported the mineral requirement of livestock to be between 0.25 $0.30 \% \mathrm{P}, 0.60-0.70 \% \mathrm{~K}, 0.50-0.60 \% \mathrm{Ca}$ and $0.10 \% \mathrm{Mg}$, thus any feed providing these mineral compositions was regarded as a high quality animal feed. Ibrahim and Hasan (2005) reported safflower whole seeds to contain $0.6 \% \mathrm{P}$ and $0.76 \% \mathrm{~K}$. Nepal Government (2012) reported that safflower whole seeds contained 0.32 and $0.24 \% \mathrm{P}$ and $\mathrm{Ca}$, respectively. The levels of $\mathrm{P}, \mathrm{K}, \mathrm{Ca}, \mathrm{Mg}$ and $\mathrm{Na}$ obtained in the present study, are higher than the suggested ranges above, implying that safflower whole seeds was a quality animal feed.

In the present study, whole safflower seeds contained 90-120 ppm $\mathrm{Zn}$ depending on genotype. USDH (2010) reported that safflower whole seeds which contained 50 ppm of $\mathrm{Zn}$ was significantly lower than our results probably because of differences in genotypes and growth environment.

The $\mathrm{Fe}$ requirements for cattle, sheep and goats are 50 and $30-75$ ppm, respectively. In the present study, safflower whole seeds contained $50-80 \mathrm{ppm}$ Fe depending on genotype, which is adequate for cattle, sheep and goats. Nepal Government (2012) and NRC (2001) reported that safflower whole seeds contained 46 and $59 \mathrm{ppm} \mathrm{Fe}$, respectively. Also in the present study, whole safflower seeds contained 30-50 ppm Mn depending on genotype which was sufficient to meet the $\mathrm{Mn}$ requirements cattle, sheep and poultry such as chicken and turkey (Smith, 1996; Weiss, 2000; Wand, 2010). USDH (2010) and Smith (1996) reported that whole safflower seeds contained 20 and 20.4 ppm Mn.

Whole safflower seeds contained 140 - 170 ppm $\mathrm{Cu}$ depending on genotype, which was above the recommended range and may cause $\mathrm{Cu}$ toxicity if Mo is deficient. USDH (2010) reported that safflower seeds contained 17.3 ppm $\mathrm{Cu}$. The results of the present study showed that safflower whole seeds are excellent sources of macro-nutrients $(\mathrm{P}, \mathrm{K}, \mathrm{Ca}$, $\mathrm{Mg}, \mathrm{Na}$ ) and micro-nutrients ( $\mathrm{Zn}, \mathrm{Fe}, \mathrm{Mn}$ and $\mathrm{Cu}$ ) for livestock feed. This suggests that whole safflower seed can be used in livestock feed and feed ration formulations.

\section{CONCLUSION}

The nutritional composition of safflower whole seed is greatly influenced by safflower genotypes and the growing season. Both 
summer and winter grown safflower yielded seed of excellent quality for animal feeding and livestock ration formulation. Due to the high $\mathrm{CP}$, fibre and macro-and micro-nutrients in safflower whole seeds, it was recommended that safflower growing be promoted in the arid-and semi-arid regions such as Botswana to serve as livestock and poultry feed, and be used for livestock feed ration formulation, for this will improve food security in the country.

\section{ACKNOWLEDGEMENT}

The authors are grateful to the MasterCard Foundation and Regional Universities Forum for Capacity Building in Agriculture (RUFORUM) for funding research and publication cost through the Transforming African Agricultural Universities to meaningfully contribute to Africa's growth and development (TAGDev) Program.

\section{REFERENCES}

Alobeid, H., Stoical, I. and Dragomir, C. 2010. Ruminal degradability andintestinal digestible protein value from safflower meal. The $39^{\text {th }}$ International Session of Scientific Communications of the Faculty of Animal Science, Bucharest, Romania 53: 105-108.

AOAC. 2000. Official methods of analysis. $17^{\text {th }}$ edition. AOAC International, Gaithersburg, MD, USA. pp. 141-147.

Ball, D.M., Collins, M., Lacefield, G.D., Martin, N.P., Mertens, D.A., Olson K.E., Putnam, D.H., Undersander, D.J. and Wolf M.W. 2017. Understanding forage quality. American Farm Bureau Federation Publication 1-01, Park Ridge, IL. 21pp. http://www.foragetesting.org/ files/ understanding/forage/quality/pdf. Accessed 25June 2017.

Bar-Tal, A., Landau, S., Li-xin, Z., Markovitz, T., Keinan, M., Dvash, L., Brener, S. and Weinberg, Z.G. 2008. Fodder quality of safflower across an irrigation gradient and with varied nitrogen rates. Agronomy Journal 100:1499-1505.

Berglund, D.R., Riveland, N. and Bergman, J. 2007. Safflower Production A-870 (Revised) http://www.ag.ndsu.edu/pubs/ plantsci/crops/a870w.htm

Bottger, J.D., Hess, B.W., Alexander, B.M., Hixon, D.L., Woodard, L.F., Funston, R.N., Hallford, D.M. and Moss, G.E. 2002. Effects of supplementation with high linoleic or oleic cracked safflower seeds on postpartum reproduction and calf performance of primiparous beef heifers. Journal of Animal Science 80:2023-2030.

Chidoh, K. 2012. Evaluation of nutritional content of safflower (Carthamus tinctorius L.) seed residue after oil extraction. Botswana College of Agriculture, Faculty of Agriculture, Crop Science and Production Department, BSc Dissertation, 26pp.

Dajue, L. and Mündel, H.H. 1996. Safflower (Carthamus tinctorius L.): Promoting the conservation and use of underutilized and neglected crops. 7. International Plant Genetic Resources Institute. pp. 1-83.

Dixon, R.M., Karda, W., Hosking, B.J. and Egan, A.R. 2003. Effects of oil seed meals and grain-ureas supplements fed infrequent on digestion in sheep. 2. Cereal straw diets. Animal Feed Science and Technology 110:95-110.

Dschaak, C.M., Eun, J.S., Young, A.J. and Bergman, J.J.W. 2010. Nutritive merits of whole nutrasaff safflower seed when fed to holstein dairy cows during mid-lactation. Animal Feed Science Technology 156:2636.

Emongor, V.E. 2009. The major cations and trace elements in Notwaneriver, Botswana and its suitability for irrigation. Botswana Journal of Agriculture and Applied Science 5(1):63-70.

Emongor, V.E. 2010. Safflower (Carthamus tinctorius L.) the underutilized and neglected crop: A review. Asian Journal of Plant Science 9(6):299-306. 
Emongor, V.E., Ramolemana, G.M. and Machacha, S. 2008. Physico-chemical properties and faecal coliform content of Notwaneriver and its suitability for irrigation. Botswana Journal of Agriculture and Applied Sciences 4(2):194-202.

French, A.V., O'Rourke, P.K. and Cameron, D.G. 1988. Beef production from forage crops in the Brigalow region of Central Queensland: 2.Winter forage crops. Tropical Grasslands 22:85-90.

Godfrey, L.R. 2006. Influence of methods of processing and feeding level of safflower seeds on the performance of dairy cows. MSc. Thesis. Utah State University, Logan, UT,United States of America.

Gohl, B. 1982. Les aliments du bétail sous les tropiques. FAO, Division of Animal Production, Roma, Italy. Available in http:/ /www.fastonline.org/CD3WD40/JF/414/ 05-222.pdf.

Hoffman, P.C. and Tayson, D. 2005. How much ash are you feeding your cows. Hoards Dairyman 149(20):659.

Ibrahim, E. and Hasan B. 2005. Deviation of some nutrients concentrations in different parts of safflower cultivars during growth stages. Pakistan Journal of Biology 37(3): 601-611.

IPNI. 1999. Phosphorus in animal nutrition. Better Crops 83(1):32-33.

Jacob, J. 2015. Feeding safflower meal to poultry. Extension organization, University of Kentuky. pp. 67353.

Malakian, M., Hassan, A.A. and Heidariniya, A. 2011. Effect of safflower seed on performance, carcass traits and blood parameters of broilers. Research Journal of Poultry Science 4(2):18-21.

Nagaraj, G. 1993. Safflower seed composition and oil quality: A review. Proceedings of the $3^{\text {rd }}$ International Safflower Conference, June14-18, 1993, Beijing, China. pp. 5871.

Nepal Government. 2012. Food composition table for Nepal. Department of Food
Technology and Quality Control. National Nutrition Program. Ministry of Agriculture Development. Research Bulletin. pp. 1516.

NRC. 2001. National Research Council, Nutrient requirements of Dairy Cattle. $7^{\text {th }}$ Revised ed. National Academy Press. Washington, DC, USA. pp. 124-248. https:/ /doi.org/10.17226/9825.

OGTR. 2015. Australian Government Department of Health, Office of the Gene Technology Regulator. The biology of Carthamus tinctorius L. (safflower). 43pp. Oguz, M.N., Oguz, F.K. and Buyukoglu, T. 2007. Effect of safflower seeds on performance, carcass traits and blood parameters of broiler chicks. Journal of Indian Veterinary 84:610-612.

Oguz, M.N., Oguz, F.K. and Buyukoglu, T.L. 2014. Effect of different concentrations of dietary safflower seed on milk yield and some rumen and blood parameters at the end stage of lactation in dairy cows. Revista Brasileirade Zootecnia 43(4):207211.

Rahamatalla, A.B., Babiker, E.E., Krishna, A.G. and El-Tinay, A.H. 1998. Changes in chemical composition, mineral and amino acids during seed growth and development of four Safflower cultivars. Journal of Plant Food and Human Nutrition 52(2): 161-170.

Schroeder, J.W. 2012. Interpreting Forage Analysis. NDSU Extension Service. AS1080. pp. 1-2.

Smith, J.R. 1996. Safflower. American Oil Chemistry Society Press, Champaign, IL, USA. 524pp.

Stanford, K., Wallins, G.L., Lees, B.M. and Mundel, H.H. 2001. Feeding value of immature safflower forage for dairy ewes. Canadian Journal of Animal Science 81:289-292.

USDH. 2010. United States Department of Health Services, Dietary guidelines for the Americans. Nutritional Data on SkipThePie.org. "Seeds. Safflower seed 
kernels, dried" SkipThePie.org.Ed. SkipThePie.2011.http://skipthepie.org/nutand-seed/products/seeds/ safflower-seedkernels-dried/. Accessed 23 August 2016.

Van Saun, R.J. 2016. Determining forage quality. Understanding feed analysis. Penn State Extension 3(8):18-26.

Van Soest, P.J., Robertson, J.B. and Lewis, B.A. 1991. Methods of dietary fibre, neutral detergent fibre and nonstarch poly saccharides in relation to animal nutrition. Journal of Dairy Science 74(10):35833597.

Voicu, D., Voicu, I., Hebean, V., Bader, L. and Câlin, A. 2009. Bioproductive and economic effect of the safflower on steer performance. Archiva Zootechnica 12(3):39-44.

Walker, J. 2006. Oilseed crops in beef rations. South Dakota State University Cooperative Extension Service. Extension Extra 2058. pp. 1-3.

Wand, C. 2010. Meeting sheep mineral requirements at pasture. Ontario Sheep News. pp. 1-2.

Weiss, E.A. 2000. Safflower. In: Weiss, E.A. Oilseed Crops, Blackwell, Science Oxford. pp. 93-129.

Wichman, D.M. 1996. Safflower for forage. In: Mündel, H.H. Braun, J. and Daniels, C. (Eds.). Proceedings of North American Safflower Conference, Great Falls, Montana, Lethbridge, AB, Canada. pp. 5660. 